\title{
Prevalência De Helicobacter Pylori Salivar E Associaçâo Com Fatores Sócio-Econômicos
}

\author{
Tabile, P.M.; Krumel, C.F.; Bassani, D.C.H.; Chaves, J.; Renner, J.D.P.; \\ Corbelini, V.A.;
}

Apresentador: Patrícia Micheli Tabile

\section{Resumo}

Introdução: Sabe-se que a prevalência de infecção pelo Helicobacter pylori (H. pylori) é maior em países subdesenvolvidos e em desenvolvimento, inferindo uma transmissão fecal-oral, estando associada a fatores socioeconômicos e falta de saneamento básico. O objetivo do estudo é avaliar a associação da prevalência de H. pylori na saliva, a partir da análise por testes microbiológicos, com os fatores socioeconômicos. Método: Estudo transversal, de abordagem quantitativa, através da análise da detecção de Helicobacter pylori salivar por métodos microbiológicos (coloração de Gram e Giemsa, cultivo) e moleculares (PCR). A amostra foi selecionada de agosto a dezembro de 2013, no município de Santa Cruz do Sul, no bairro Bom Jesus e entre os funcionários da Universidade. A amostra totalizou 104 pacientes de ambos os sexos, sem restrição de idade. Na coleta, aplicou-se um questionário sobre idade, local de moradia, nível socioeconômico (critério ABEP) e saneamento básico. Os dados obtidos foram analisados no SPSS 19.0. Resultados: No total, 104 pacientes entraram no estudo. Destes, $42,3 \%$ eram homens e $51 \%$ solteiros. A idade média foi 33,9 anos. Todos os domicílios possuem água encanada e apenas $89,4 \%$ possuem esgoto. A média de pontos no critério ABEP foi 22,67 - a maioria dos indivíduos era da classe B e C (40,4\% e 42,3\%, respectivamente). Onze indivíduos eram da classe $\mathrm{D}$ $(10,6 \%)$. Do total, $36(34,6 \%)$ apresentavam o exame da saliva pela coloração Gram e Giemsa positivos para H. pylori, 13 apresentaram cultura positiva. No estudo, os funcionários da universidade tiveram uma prevalência maior de H. pylori em relação aos moradores do Bairro Bom Jesus (53,1\% e 26,4\%, respectivamente, $p=0,008)$. Entretanto, os mesmos apresentam um nível socioeconômico maior, sendo que $75 \%$ estão na classe A e B, contra $34,7 \%$ dos moradores do bairro. Conclusões: Assim observa-se que apenas o sexo masculino e estar casado parecem ser fatores protetores para a presença de $\mathrm{H}$. pylori salivar. O estudo não permite explicar porque os funcionários da universidade tem uma maior prevalência da bactéria em relação aos moradores do bairro. Logo, para elucidação destas questões, é necessário aumentar o tamanho da amostra, investigar os hábitos higienodietéticos da nossa população e comparar esse método diagnóstico com outros.

\section{Referência:}

Tabile, P.M.; Krumel, C.F.; Bassani, D.C.H.; Chaves, J.; Renner, J.D.P.; Corbelini, V.A.;. Prevalência De Helicobacter Pylori Salivar E Associaçâo Com Fatores Sócio-Econômicos. In: Il Congresso Brasileiro de Medicina Hospitalar - II CBMH [= Blucher Medical Proceedings, vol.1, num.5] São Paulo: Editora Blucher, 2014. p.66

DOI 10.5151/medpro-II-cbmh-063 